\title{
A Review of Air Pollution and Control in Hebei Province, China
}

\author{
Litao Wang, Jing Yang, Pu Zhang, Xiujuan Zhao, Zhe Wei, Fenfen Zhang, Jie Su, Chenchen Meng \\ Department of Environmental Engineering, Hebei University of Engineering, Handan, China \\ Email: wanglitao@hebeu.edu.cn
}

Received June 19, 2013; revised July 25, 2013; accepted August 1, 2013

Copyright (C) 2013 Litao Wang et al. This is an open access article distributed under the Creative Commons Attribution License, which permits unrestricted use, distribution, and reproduction in any medium, provided the original work is properly cited.

\begin{abstract}
Hebei is one of the most air polluted provinces in China. According to the Ministry of Environmental Protection (MEP) for the severe fog-haze month of Jan. 2013, seven of the top ten most polluted cities in China are located in Hebei Province. In this study, the air pollution history and status of the Hebei Province are reviewed and discussed, using the governmental published Air Pollution Index (API), the academic observations by various scientific research groups and the long-term statistics of visibility and haze frequencies. It is found that within the Hebei Province, the air pollution in the southern cities is much more severe than the northern cities. Particulate matter (PM) is undoubtedly the major air pollutant, sulfur dioxide $\left(\mathrm{SO}_{2}\right)$ and nitrogen oxides $\left(\mathrm{NO}_{\mathrm{X}}\right)$ pollutions are also unnegligible. Ozone $\left(\mathrm{O}_{3}\right)$ pollution in larger cities, such as Shijiazhuang, is significant. Air pollution control history from 1998 is discussed as well. Although Hebei Province has made a great effort on air quality, the pollutant emissions, such as $\mathrm{SO}_{2}$ and fly ash, showed a notable increase in 2001 to 2006. However, after 2006 the emissions started to decrease due to the strict implementation of the national 11th Five Year Plan (FYP). In addition, regional jointly air pollution control and prevention strategies are expected in the future to substantially change the severe air pollution status in Hebei Province.
\end{abstract}

Keywords: Air Quality; Hebei; API; $\mathrm{PM}_{2.5}$

\section{Introduction}

In Jan. 2013, continuous, severe haze pollution happened in east and central China, attracting the most public attention. In Beijing, only five days were not fog and haze days during Jan. 2013. It is reported that the daily fine particulate matter $\left(\mathrm{PM}_{2.5}\right)$ concentrations in Beijing and Shijiazhuang has been over $500 \mu \mathrm{g} \cdot \mathrm{m}^{-3}$, which is 6.7 times of the new China National Ambient Air Quality Standard (CNAAQS) [1]. In the statistics of the Ministry of Environmental Protection of China (MEP), during this month, the ten most polluted cities are Xingtai, Shijiazhuang, Baoding, Handan, Langfang, Hengshui, Jinan, Tangshan, Beijing and Zhengzhou city, out of the reported 74 key cities all over China (http://hebei.sina. com.cn/news/yz/2013-02-06/075733562.html). It should be noted that in these ten top polluted cities, seven cities are within Hebei Province and five of them are located in the southern area of Hebei (see Figure 1). The air pollution in Hebei Province has aroused wide public concern.

Hebei Province, located in the north-east of China, is east to the Taihang Mountains and north to the Yellow River (see Figure 1). It encloses two municipal cities,
Beijing and Tianjin. The neighboring provinces (in clockwise direction) are Shandong Province, Henan Province, Shanxi Province, Inner Mongolia Autonomous Region and Liaoning Province. It has the area of $187,700 \mathrm{sq} \cdot \mathrm{km}$ and population of 71.85 million (http://www.stats.gov.cn/ tjgb/rkpcgb/dfrkpcgb/t20120228_402804324.htm). Most of the northwest area of Hebei is mountainous or hilly, while the central and south areas belong to North China Plain. Hebei has a monsoon climate of medium latitudes, which has dry and windy springs, hot and rainy summers and dry-cold winters.

In 2011, Hebei's Gross Domestic Product (GDP) is 2.45 trillion RMB, accounting for $5.18 \%$ of national GDP and ranking 6th in China [2]. The major industries in Hebei are iron, steel, coke and cement. In 2011, 45.5\% of the steel in the world was produced in China, out of which $24.0 \%$ was produced in Hebei [2]. China's coke production accounted for more than $60 \%$ of the world, of which $14.5 \%$ was produced in Hebei [3]. Hebei's cement production was $6.9 \%$ of the national total amount [2]. The air pollution burden of the southern Hebei area is particularly heavy because of its special location. It is sur- 


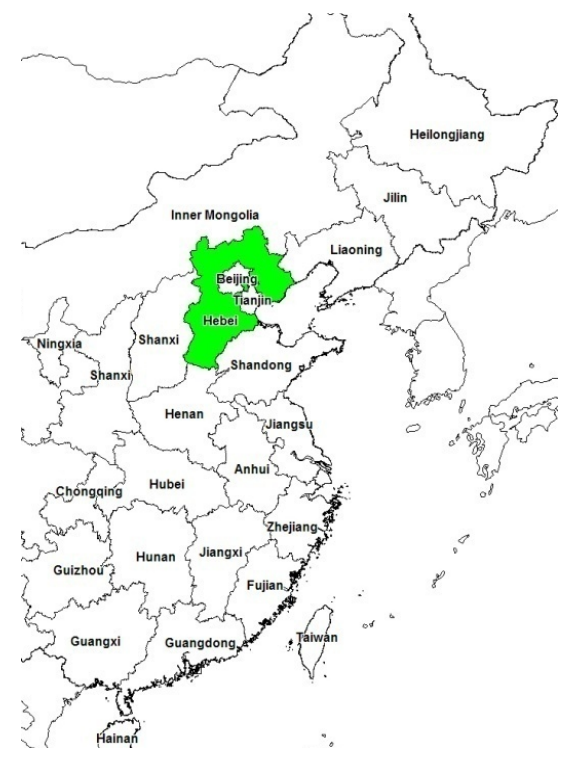

(a)

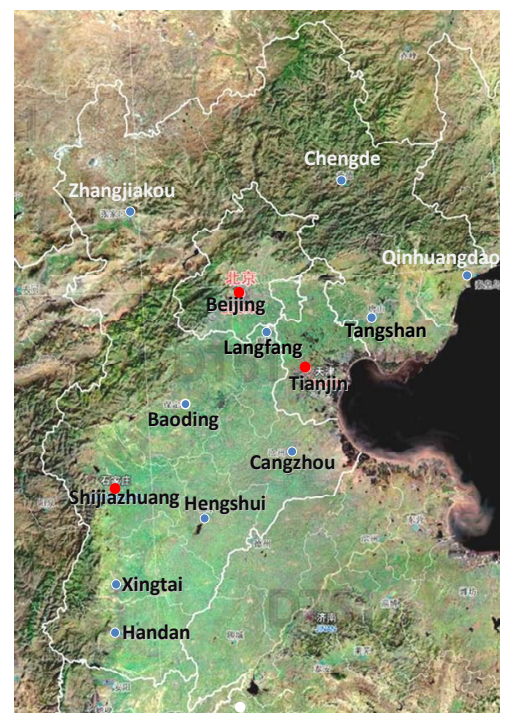

(b)

Figure 1. Location of Hebei Province and the cities: (a) locations of Hebei Province in China; (b) eleven cities in Hebei Province.

rounded by the other three populated and industrialized provinces, Shandong, Henan and Shanxi. The steel, coke and cement productions of the four neighbored provinces are as large as $40.8 \%, 50.1 \%$ and $22.6 \%$ of the national total amount. That is to say, $18.6 \%$ of steel production in the world, $30.0 \%$ of the coke and $13.6 \%$ of the cement were yielded in this area.

The large industrial productions induce huge quantities of pollutants emission. In the widely-used Asian INTEX$\mathrm{B}$ emission inventory [4], the $\mathrm{PM}_{2.5}$ emissions from the four provinces accounted for $28 \%$ of the national total emission in 2006. The percentages for $\mathrm{SO}_{2}, \mathrm{NO}_{\mathrm{X}}, \mathrm{CO}$, VOC, BC and OC were $28 \%, 25 \%, 28 \%, 24 \%, 30 \%$ and $24 \%$. It gives us a clue why Hebei Province, especially the southern area, has the most severe air pollution all over China.

Hebei is somewhat overshadowed by its two neighbors, Beijing and Tianjin. Like other aspects, its air pollution problems haven't been paid enough attention for a long time. Very few studies have focused on the air pollution status in Hebei area, analyzed the present control strategies and given relative suggestions. In the 12th FYP of Air Pollution Control in the Key Regions by MEP at the end of 2012 (http://www.mep.gov.cn/gkml/hbb/bwj/2012 12/t20121205_243271.htm), Beijing, Tianjin and Hebei area is one the three key air pollution control regions and will be pursued regional jointly air pollution prevention and control. Better strategies and more effective actions should be expected in Hebei area. In this paper, we summarize the air quality history and status according to both the governmental reports and the relative academic studies, and also review the air pollution control meas- urements pursued within Hebei area and give suggestions on future pollution control.

\section{Air Pollution History and Status}

\subsection{API and AQI}

The API is a non dimensional number calculated according to the urban daily average concentrations of three pollutants: $\mathrm{SO}_{2}$, nitrogen dioxide $\left(\mathrm{NO}_{2}\right)$ and coarse particulate matter $\left(\mathrm{PM}_{10}\right)$. Besides of the simplicity, it provided the only publicly accessible urban air quality data before the real time concentrations of the three pollutants of the national sites were started to be published online in 2011. The API record of the key environmental protecttion cities from 2000 is on the website of the Ministry of Environmental Protection (http://datacenter.mep.gov.cn/). The detailed introduction of API system can be found on in [5].

Before 2003, only Shijiazhuang, the capital city of Hebei was listed in the China's key environmental protection cities and had the API record on the website of MEP from 2000. In Feb. 2011, three other Hebei cities, Tangshan, Baoding and Handan started to publish their APIs. Figure 2 provides the distribution of the APIs in Shijiazhuang from 2001 to 2012. It can be seen that in general, air quality in Shijiazhuang city was visibly improved in 2001 to 2009. The number of the days with the APIs less than or equal to 50 (which is also "no key pollutant" day, see [5]) and between 50 - 100 was notably increased from 0 and 93 in 2001, to 43 and 274 in 2012, respectively. And the days having the APIs in $100-150$ and $150-200$ decreased, respectively, from 168 and 79 
in 2001, to 44 and 2 in 2009. The severely polluted days, in which the API was higher than 300 , decline from 12 to 0 in 2001 to 2009.

After 2009, the pollution level kept relatively stable. The frequencies of the APIs within 150 - 200 even increased from 2 days in 2009 to 10 days in 2012 (note that the API less than 100 means the city's air quality reach the CNAAQS [6]. The annual average APIs were 77.5, 74.6, 75.5, and 74.1 in 2009, 2010, 2011 and 2012, respectively. This number is 138.3 in $2001,91.7$ in 2005 , and 83.5 in 2008 .

Figure 3 shows the time series of API in Shijiazhuang city in the past five years. It is shown that the daily variations of APIs were consistent for the five years, that the best air quality appeared in Sep., Aug. and Jul., with the three-month-average APIs of 55.5 (2012) to 66.9 (2008). Then followed Jun., May and Feb. Winter was the worst season that the monthly average APIs were within 69.6 (2010) to 114.0 (2012) for Jan., 78.8 (2011) to 87.8 (2008) for Nov., and 89.1 (2009) to 111.1 (2010) for Dec. In Mar. and Apr. 2008, the APIs indicated two pollution episodes induced by sand storms. Despite the two episodes, the average APIs were 55.9 (2011) to 76.0 (2010) for Mar., and 72.2 (2011) to 89.3 (2009) for Apr. Other information indicated by Figure 3 is that the air quality in Shijiazhuang didn't show noticeable improvement or deterioration during the recent five years, which is consistent with the above discussions.

Since February 2011, three other cities, Tangshan, Baoding and Handan started to release their APIs on the website of MEP. To compare with Shijiazhuang city, Figure 4 presents the time series of APIs for the four cities from 2010 to Jan. 14, 2013. In general, Shijiazhuang city had the worst air quality that the average API

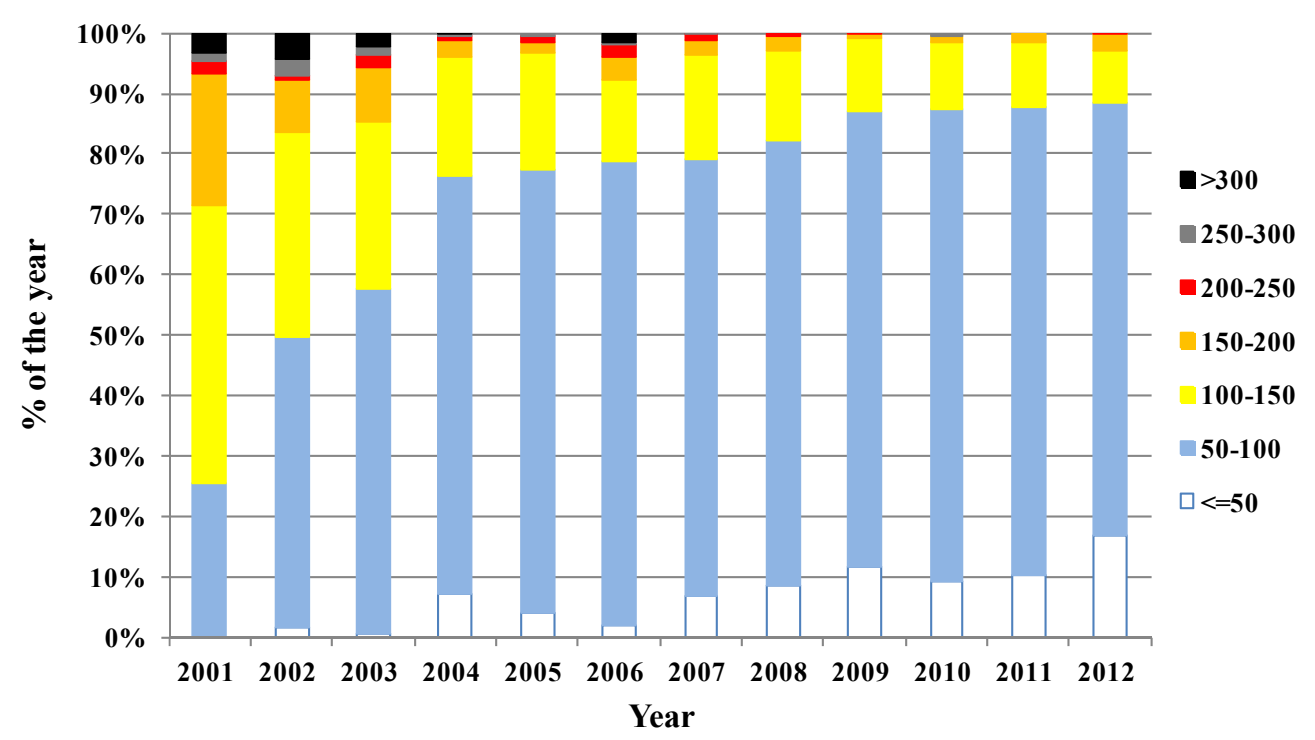

Figure 2. API distribution in Shijiazhuang city in 2001-2012.

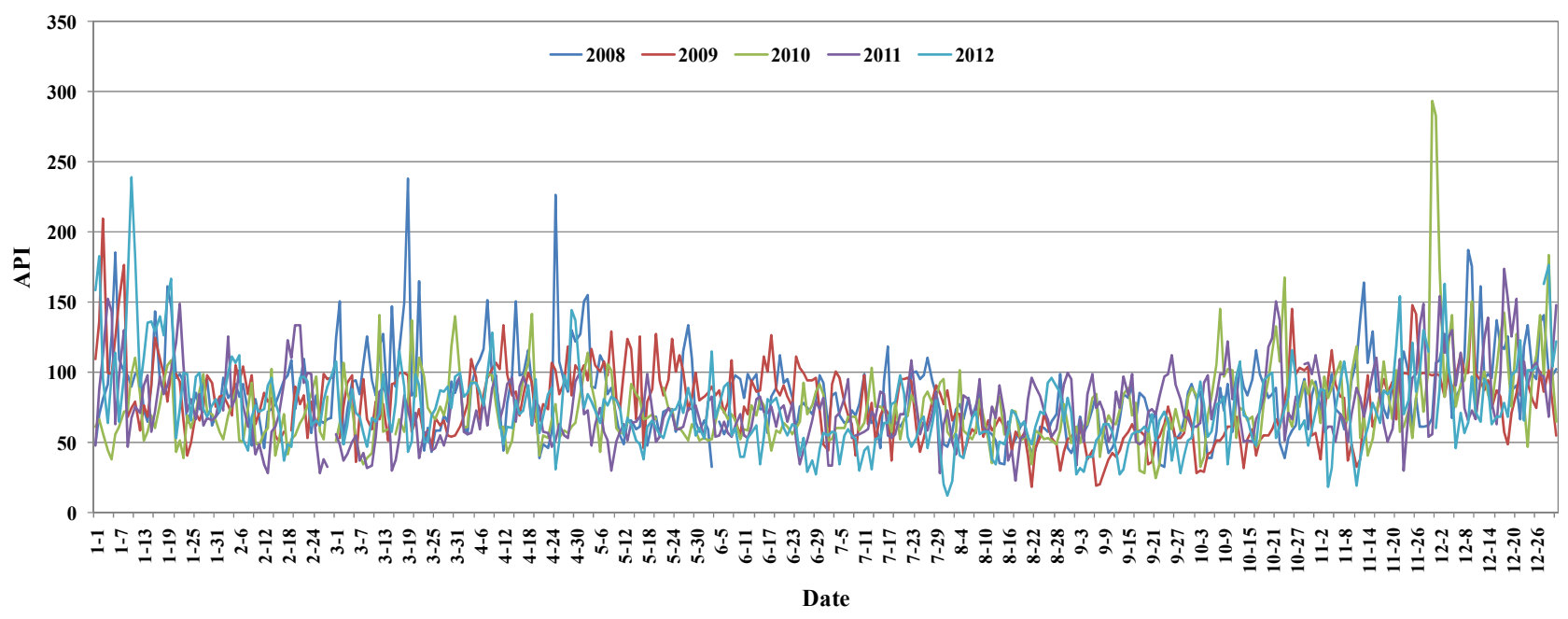

Figure 3. Time series of API in Shijiazhuang in 2008-2012. 
in Feb. 2012 to Jan. 2013 was 83.3. Then was Handan city, with the average API of 73.6 during the same period. Baoding and Tangshan city had the average numbers of 70.8 and 69.4 , respectively.

At the end of 2010, there was a severe pollution episode in Shijiazhuang city, with the API of near 300 (as $420 \mu \mathrm{g} \cdot \mathrm{m}^{-3}$ of daily average $\mathrm{PM}_{10}$ ). At the end of 2011 , Shijiazhuang city didn't show big difference in pollutant character from 2010, but a highly polluted episode happened in Handan city that the largest API was as high as 348 (as $458 \mu \mathrm{g} \cdot \mathrm{m}^{-3}$ of daily average $\mathrm{PM}_{10}$ ). In this month (Dec. 2011), the average APIs were 118.1, 102.9, 100.1 and 92.1 for Handan, Baoding, Tangshan and Shijiazhuang, respectively.

As discussed above, very severe haze pollution happened over east China in the winter of 2012, in which Beijing-Tianjin-Hebei area was one of the most polluted regions. It is clearly indicated in Figure 4. The APIs reached the top limit, 500 (representing $600 \mu \mathrm{g} \cdot \mathrm{m}^{-3}$ of daily average $\mathrm{PM}_{10}$ ). It is four times of the CNAAQS. One of the most possible reasons might be the special meteorological conditions, comparing with the former two years. Lots of investigations are needed before drawing a convictive conclusion of this episode.

In Feb. 2012, the MEP released the new CNAAQS [7], which will be implemented in 2016, and the new technical regulations on air quality daily reports [8]. In the new system, more pollutants, such as $\mathrm{CO}, \mathrm{O}_{3}$ and $\mathrm{PM}_{2.5}$, are involved and API is replaced by Air Quality Index (AQI).

From Jan. 2013, the MEP started to publish the realtime concentrations of $\mathrm{SO}_{2}, \mathrm{NO}_{2}, \mathrm{CO}, 1-\mathrm{hr}$ and 8-hr $\mathrm{O}_{3}$, $\mathrm{PM}_{10}$ and $\mathrm{PM}_{2.5}$, as well as their AQIs, of all the national monitoring sites in the 74 cities including the capitals, major cities in Beijing-Tianjin-Hebei area, Yangtze River
Delta, and Pearl River Delta (http://113.108.142.147: 20035/emcpublish/). At the same time the old daily APIs for those cities were stopped to update after Jan. 14, 2013. It is a progress that more detailed information on air quality can be accessed on the real time system, but it is a pity that up to now, the users could not access any longer history data except for the data for the past 24 hours. More understanding on the past special winter might be obtained when the historical real time data are accessible from the system.

\subsection{Academic Observations}

The largest scale of air quality observations over the Beijing-Tianjin-Hebei area were pursued by the Institute of Atmospheric Physics, Chinese Academy of Science (IAP, CAS) [9]. 25 monitoring stations were established in northern China by IAP since 2009, out of which 16 were located in Hebei area [9], involving nine cities: Shijiazhuang, Baoding, Tangshan, Hengshui, Cangzhou, Langfang, Chengde, Zhangjiakou, and Qinhuangdao. $\mathrm{PM}_{10}$, $\mathrm{SO}_{2}$ and $\mathrm{NO}_{\mathrm{X}}$ were observed in these stations. Table 1 summarizes the results of these studies and the observations carried out by the other researchers. It is listed according to the locations of the observation sites, from the north to the south of Hebei.

The northest site is Xinglong, located in the Chengde city. It is only the rural and background site in the table. The daily average concentrations of $\mathrm{PM}_{10}, \mathrm{SO}_{2}, \mathrm{NO}_{\mathrm{X}}$ and $\mathrm{O}_{3}$ didn't exceed the present CNAAQS [6], neither the maximum daily concentrations. Only the maximum hourly $\mathrm{O}_{3}$ concentrations exceeded the standard $\left(291 \mu \mathrm{g} \cdot \mathrm{m}^{-3}\right.$, $46 \%$ higher than the CNAAQS). $\mathrm{O}_{3}$ pollution at this background site is unnegligible according to the observations [10], which may be induced by the large quantities of pollutant emissions for the near huge cities.

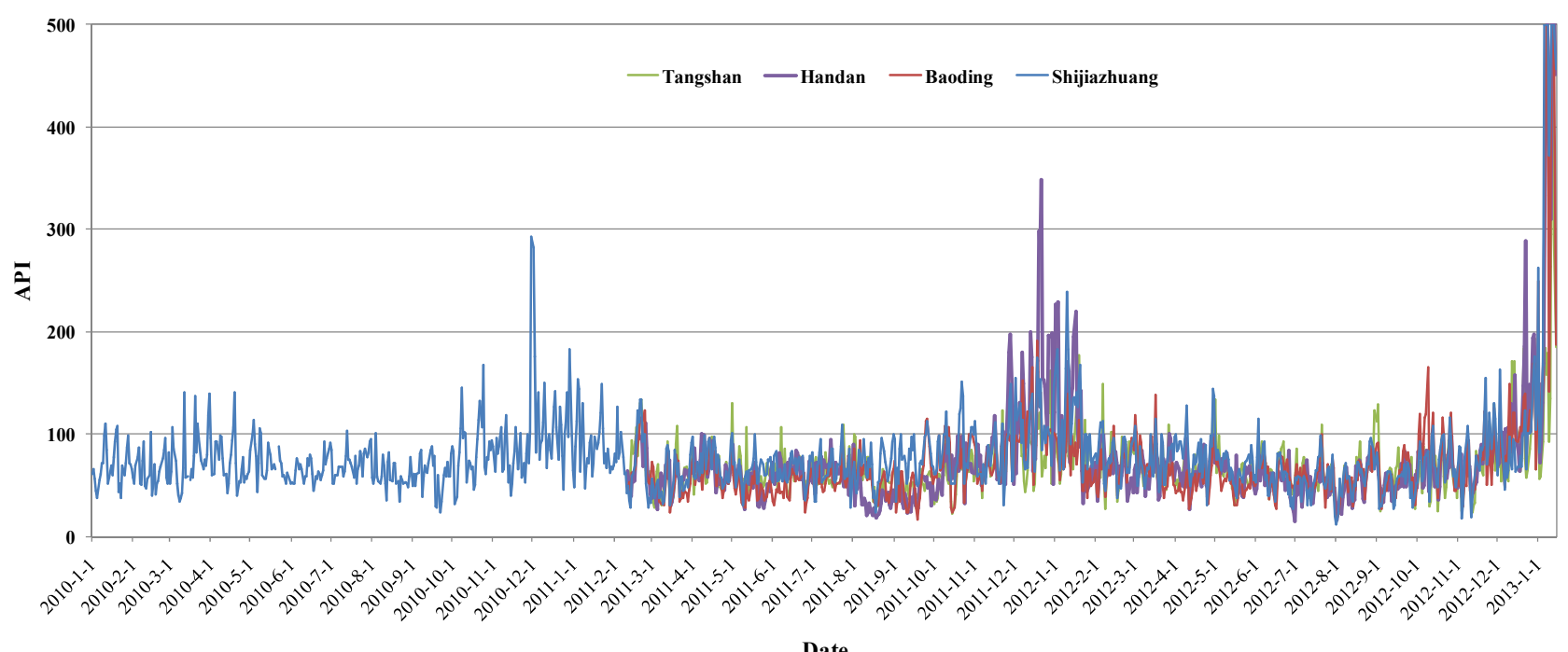

Figure 4. Time series of API in Tangshan, Handan, Baoding and Shijiazhuang in 2010-2012. 
Table 1. Air quality observations in Hebei Province (unit: $\mu \mathrm{g} \cdot \mathrm{m}^{-3}$ ).

\begin{tabular}{|c|c|c|c|c|c|c|c|c|c|c|c|c|}
\hline Site & Period & Environment & City size & Region & $\begin{array}{l}\text { Daily } \\
\mathbf{P M}_{10}\end{array}$ & $\begin{array}{l}\text { Daily } \\
\mathbf{P M}_{2.5}\end{array}$ & $\begin{array}{c}\text { Daily } \\
\mathrm{SO}_{2}\end{array}$ & $\begin{array}{l}\text { Daily } \\
\mathrm{NO}_{2}\end{array}$ & $\begin{array}{l}\text { Daily } \\
\text { NO }_{x}\end{array}$ & Daily $\mathrm{O}_{3}$ & $\begin{array}{c}\text { Hourly } \\
\mathbf{O}_{3}\end{array}$ & Ref. \\
\hline Xinglong & $\begin{array}{c}\text { Aug. 15- } \\
\text { Sep. 15 } \\
2006\end{array}$ & $\begin{array}{c}\text { Rural and } \\
\text { background }\end{array}$ & $\begin{array}{l}\text { County-level } \\
\text { city }\end{array}$ & Chengde & $\begin{array}{l}69.4(7.0 \\
-141.2)^{\mathrm{a}}\end{array}$ & - & $\begin{array}{c}4.4(0.2- \\
17.2)^{\mathrm{a}}\end{array}$ & - & $\begin{array}{l}15.1(5.9 \\
-22.1)^{\mathrm{a}}\end{array}$ & - & $\begin{array}{c}137(21- \\
291)^{\mathrm{a}}\end{array}$ & [10] \\
\hline Xianghe & $\begin{array}{c}\text { Jun.-Sep. } \\
2008\end{array}$ & Rural & $\begin{array}{l}\text { County-level } \\
\text { city }\end{array}$ & Langfang & $\begin{array}{c}113 \pm 52 \\
(248)^{\mathrm{b}}\end{array}$ & $\begin{array}{c}76 \pm 42 \\
(184)^{\mathrm{b}}\end{array}$ & $\begin{array}{c}13.4 \pm \\
15.2 \\
(84.4)^{\mathrm{b}}\end{array}$ & $\begin{array}{c}14.5 \pm \\
8.6 \\
(41.0)^{\mathrm{b}}\end{array}$ & $\begin{array}{c}15.9 \pm \\
9.1 \\
(43.3)^{\mathrm{b}}\end{array}$ & $\begin{array}{c}82 \pm 38 \\
(230)^{b}\end{array}$ & - & [11] \\
\hline Tangshan & $\begin{array}{c}\text { Jun.-Aug. } \\
2007\end{array}$ & $\begin{array}{l}\text { Cultural and } \\
\text { educational }\end{array}$ & City & Tangshan & - & $\begin{array}{c}109.8 \pm \\
26.4\end{array}$ & - & $\begin{array}{c}41.7 \pm \\
7.6\end{array}$ & - & $\begin{array}{c}66.7 \pm \\
16.8\end{array}$ & $\begin{array}{c}157.8 \pm \\
42.5\end{array}$ & [12] \\
\hline Tangshan & $\begin{array}{c}\text { Sep.-Oct, } \\
2007\end{array}$ & $\begin{array}{l}\text { Cultural and } \\
\text { educational }\end{array}$ & City & Tangshan & - & $\begin{array}{c}150.9 \pm \\
58.1\end{array}$ & - & $\begin{array}{c}46.0 \pm \\
8.9\end{array}$ & - & $\begin{array}{c}46.4 \pm \\
25.8\end{array}$ & $\begin{array}{c}123.5 \pm \\
61.4\end{array}$ & {$[12]$} \\
\hline Tangshan & $\begin{array}{c}\text { Jun.-Aug. } \\
2008\end{array}$ & $\begin{array}{l}\text { Cultural and } \\
\text { educational }\end{array}$ & City & Tangshan & - & $\begin{array}{c}103.9 \pm \\
50.3\end{array}$ & $\begin{array}{c}44.8 \pm \\
31.1\end{array}$ & $\begin{array}{c}38.6 \pm \\
10.5\end{array}$ & - & $\begin{array}{c}74.6 \pm \\
25.8\end{array}$ & $\begin{array}{c}153.0 \pm \\
52.8\end{array}$ & [12] \\
\hline Tangshan & $\begin{array}{c}\text { Sep.-Oct. } \\
2008\end{array}$ & $\begin{array}{l}\text { Cultural and } \\
\text { educational }\end{array}$ & City & Tangshan & - & $\begin{array}{c}91.9 \pm \\
62.4\end{array}$ & $\begin{array}{c}52.2 \pm \\
25.2\end{array}$ & $\begin{array}{c}40.4 \pm \\
12.6\end{array}$ & - & $\begin{array}{c}42.4 \pm \\
21.4\end{array}$ & $\begin{array}{c}108.3 \pm \\
52.5\end{array}$ & [12] \\
\hline Zhuozhou & $\begin{array}{l}\text { Jul. 2009- } \\
\text { Feb. } 2011\end{array}$ & $\begin{array}{l}\text { Cultural and } \\
\text { educational }\end{array}$ & $\begin{array}{l}\text { County-level } \\
\text { city }\end{array}$ & Baoding & 153 & - & 27 & - & 68 & 44 & - & [13] \\
\hline Baoding & $\begin{array}{l}\text { Jul. 2009- } \\
\text { Feb. } 2011\end{array}$ & $\begin{array}{l}\text { Cultural and } \\
\text { educational }\end{array}$ & City & Baoding & 189 & - & 72 & - & 83 & 48 & - & [13] \\
\hline Shijiazhuang & $\begin{array}{l}\text { Aug. 12- } \\
\text { Sep. 25 } \\
2007\end{array}$ & $\begin{array}{l}\text { Cultural and } \\
\text { educational }\end{array}$ & Capital city & Shijiazhuang & - & $\begin{array}{c}114.5 \pm \\
45.3\end{array}$ & - & $\begin{array}{c}51.9 \pm \\
11.0\end{array}$ & - & $\begin{array}{c}81.3 \pm \\
35.6\end{array}$ & $\begin{array}{c}166.7 \pm \\
67.1\end{array}$ & [14] \\
\hline Shijiazhuang & $\begin{array}{c}\text { Jun.-Sep. } \\
2008\end{array}$ & $\begin{array}{l}\text { Cultural and } \\
\text { educational }\end{array}$ & Capital city & Shijiazhuang & $\begin{array}{c}150.7 \pm \\
62.1\end{array}$ & $\begin{array}{c}99.4 \pm \\
48.6\end{array}$ & $\begin{array}{c}80.2 \pm \\
36.6\end{array}$ & $\begin{array}{c}43.9 \pm \\
19.8\end{array}$ & - & $\begin{array}{c}64.0 \pm \\
33.9\end{array}$ & $\begin{array}{c}148.6 \pm \\
71.5\end{array}$ & [14] \\
\hline Shijiazhuang & $\begin{array}{l}\text { Jul. 2009- } \\
\text { Feb. } 2011\end{array}$ & $\begin{array}{l}\text { Cultural and } \\
\text { educational }\end{array}$ & City & Shijiazhuang & 204 & - & 87 & - & 74 & 34 & - & [13] \\
\hline Handan & $\begin{array}{c}\text { Aug.-Oct. } \\
2012\end{array}$ & $\begin{array}{l}\text { Cultural and } \\
\text { educational }\end{array}$ & City & Handan & $\begin{array}{c}196.5 \pm \\
107.1\end{array}$ & $\begin{array}{c}96.7 \pm \\
55.2\end{array}$ & $\begin{array}{c}69.2 \pm \\
31.4\end{array}$ & $\begin{array}{c}37.0 \pm \\
26.3\end{array}$ & $\begin{array}{c}66.3 \pm \\
31.4\end{array}$ & $\begin{array}{c}67.5 \pm \\
22.9\end{array}$ & $\begin{array}{c}135.8 \pm \\
53.4\end{array}$ & {$[15]$} \\
\hline Handan & $\begin{array}{c}\text { Nov.- } \\
\text { Dec. } 2012\end{array}$ & $\begin{array}{l}\text { Cultural and } \\
\text { educational }\end{array}$ & City & Handan & $\begin{array}{c}248.6 \pm \\
102.4\end{array}$ & $\begin{array}{c}121.5 \pm \\
60.4\end{array}$ & $\begin{array}{c}142.4 \pm \\
56.4\end{array}$ & $\begin{array}{c}51.9 \pm \\
12.5\end{array}$ & $\begin{array}{c}130.0 \pm \\
53.9\end{array}$ & 14. \pm 8.6 & $\begin{array}{c}40.5 \pm \\
16.7\end{array}$ & [15] \\
\hline Handan & Jan. 2013 & $\begin{array}{l}\text { Cultural and } \\
\text { educational }\end{array}$ & City & Handan & $\begin{array}{c}347.2 \pm \\
174.6\end{array}$ & $\begin{array}{c}233.4 \pm \\
144.4\end{array}$ & $\begin{array}{c}222.6 \pm \\
86.5\end{array}$ & $\begin{array}{c}93.3 \pm \\
25.2\end{array}$ & $\begin{array}{c}215.6 \pm \\
72.7\end{array}$ & & $\begin{array}{c}22.0 \pm \\
14.8\end{array}$ & {$[15]$} \\
\hline
\end{tabular}

aThe data is "average(minimum-maximum)"; ${ }^{\mathrm{b}}$ The data is "average \pm standard deviation (maximum)". Other data is "average" or "average \pm standard deviation".

Xianghe site is in Langfang city, between Beijing and Tianjin city. The average $\mathrm{PM}_{10}, \mathrm{SO}_{2}$ and $\mathrm{NO}_{\mathrm{X}}$ didn't exceed the present daily standard during the summer of 2008 , but the $\mathrm{PM}_{2.5}$ concentration were slightly higher than the new CNAAQS for daily $\mathrm{PM}_{2.5}$ concentrations $\left(75 \mu \mathrm{g} \cdot \mathrm{m}^{-3}\right)$. Note that this was the Beijing Olympic period, during which air quality were much better than the normal situation.

Tangshan is one of the heavy industry bases in China. From the Table 1 we can found that PM was the key pollutant in Tangshan. Even in the Olympic period (Jun.Aug. 2008), the average $\mathrm{PM}_{2.5}$ concentration were $39 \%$ higher than the new standard for daily $\mathrm{PM}_{2.5}$. Zhuozhou and Baoding site showed the same characteristics that PM was the most important pollutant. Their average $\mathrm{PM}_{10}$ concentrations during Jul. 2009 to Feb. 2011 were
153 and $189 \mu \mathrm{g} \cdot \mathrm{m}^{-3}$, respectively, much higher than the annual limit of $\mathrm{PM}_{10}\left(100 \mu \mathrm{g} \cdot \mathrm{m}^{-3}\right) . \mathrm{SO}_{2}$ in Baoding site exceeded the national annual standard $\left(60 \mu \mathrm{g} \cdot \mathrm{m}^{-3}\right)$, and $\mathrm{NO}_{\mathrm{X}}$ in both Zhuozhou and Baoding site exceeded the new national annual standard $\left(50 \mu \mathrm{g} \cdot \mathrm{m}^{-3}\right)$.

According to Table 1, Shijiazhuang, the capital city of Hebei, and Handan, the southest city in Hebei, were the two most polluted cities. The $\mathrm{PM}_{10}$ and $\mathrm{PM}_{2.5}$ concentrations in all observed periods were exceeding the CNAAQS. In Shijiazhuang, the average $\mathrm{PM}_{10}$ concentrations were $204 \mu \mathrm{g} \cdot \mathrm{m}^{-3}$ for Jul. 2009 to Feb. 2011, which was about two times of the present annual limit. $\mathrm{PM}_{2.5}$ concentration, even in Olympic period, was 1.3 times of new CNAAQS. Observation studies in Handan were pursued since Aug., 2012. The average $\mathrm{PM}_{10}$ and $\mathrm{PM}_{2.5}$ concentrations could reach 248.6 and $121.5 \mu \mathrm{g} \cdot \mathrm{m}^{-3}$ in the 
winter of 2012, which is about 1.6 times of the present $\mathrm{PM}_{10}$ limit and the new standard for $\mathrm{PM}_{2.5}$. As discussed above, Jan. 2013 was quite special and highly polluted. During this month, the average $\mathrm{PM}_{10}$ and $\mathrm{PM}_{2.5}$ concentrations were 347.2 and $233.4 \mu \mathrm{g} \cdot \mathrm{m}^{-3}$, respectively, which were 2.3 and 3.1 times of the daily limit. $\mathrm{SO}_{2}$ and $\mathrm{NO}_{\mathrm{X}}$ in wintertime were also unnegligible in Shijiazhuang and Handan city. $\mathrm{SO}_{2}$ pollution in Shijiazhuang was more severe than in Baoding, and $\mathrm{NO}_{\mathrm{X}}$ was on the contrary. Comparing with Handan, $\mathrm{O}_{3}$ pollution in Shijiazhuang city was more serious according to the limited data. Long-term observations are needed to understand the air pollution characteristics in the southern Hebei cities.

In intercomparison with other cities outside Hebei, Wu's study [13] compared the $\mathrm{PM}_{10}, \mathrm{SO}_{2}, \mathrm{NO}_{\mathrm{X}}$ and $\mathrm{O}_{3}$ concentrations in Beijing, Zhuozhou (a county-level city within Baoding), Baoding and Shijiazhuang and concluded that during the monitoring period (Jul. 2009-Feb. 2011), Shijiazhuang city had highest concentrations of $\mathrm{PM}_{10}$ and $\mathrm{SO}_{2}$. The highest NOx concentrations appeared in Beijing and the most severe $\mathrm{O}_{3}$ pollution happened in Baoding. And during the three years, $\mathrm{NO}_{\mathrm{X}}$ concentrations were increasing and $\mathrm{SO}_{2}$ 's were decreasing. $\mathrm{O}_{3}$ and $\mathrm{PM}_{10}$ concentrations kept stable.

In [9], two severe pollution episodes over North China were reported in the period of Oct. 27 to Nov. 10 in 2009. In the comparison of Beijing, Tianjin and nine cities in Hebei (except Xingtai and Handan city), the highest daily $\mathrm{PM}_{10}$ concentration appeared in Shijiazhuang of 600 $\mu \mathrm{g} \cdot \mathrm{m}^{-3}$, four times of the national limit of $150 \mu \mathrm{g} \cdot \mathrm{m}^{-3}$. Another important conclusion is that the heavy pollution episodes were characterized by nearly uniform concentrations over northern China and directly related to the strength and duration of the southern flows. And the meteorological conditions of light wind, temperature reversion and low mixed layer were important contributors to the increase of PM.

In Liu et al.'s study [16], $\mathrm{PM}_{10}$ were sampled during Sep. to Oct. 2005 all over Hebei Province, Beijing and Tianjin City, to analysis the PAH pollution. They found that the highest $\mathrm{PM}_{10}$ concentration appeared in Handan and Shijiazhuang and the PAH pollution were most serious in Handan, Shijiazhuang and Tangshan.

In general, air pollution in the southern cities is more severe than in the northern cities in Hebei. PM is undoubtedly the key pollutant. $\mathrm{SO}_{2}$ and $\mathrm{NO}_{\mathrm{X}}$ are unnegligible and $\mathrm{O}_{3}$ pollution in larger cities is also significant, indicating that the both the coal-burning emissions and the mobile sources should be considered in the air pollution controls.

\subsection{Visibility and Haze Frequencies}

Visibility might be seen, to some extent, as an indicator of air quality. It has a longer history data for analysis. Che et al. gathered the visibility data from 1981 to 2005 of 615 meteorological stations in mainland China and found that $71 \%$ of these stations observed a visible deterioration and this trend became more clear after 1990 [17]. The highest haze frequencies happen in three areas: North China, the Yangtze River Delta and the Pearl River Delta. And the rapid increase in haze frequencies occurs in the middle and southern areas of North China Plain, the middle and lower reaches of the Yangtze River, and South China. The North China area has both the highest number of haze days and the most rapid growth in haze frequency [18].

Within North China area, Zhao [19] analyzed the data from 100 stations in Beijing-Tianjin-Hebei area from 1980 to 2008 and found that the southern cities in Hebei, such as Shijiazhuang, Xingtai and Handan had the lowest visibility of $10-14 \mathrm{~km}$ on annual average (Beijing was $15-20 \mathrm{~km}$ ) since 1990. In comparison with other cities using the data from 743 stations all over China, the haze frequency in Xingtai City ranked second on average from 1951 to 2005, and became the first after the mid 1990s [20].

Wang et al. [18] analyzed the haze frequencies in 2001 to 2010 of the seven typical cities in North China, Beijing, Tianjin, Shijiazhuang, Xingtai, Taiyuan, Zhengzhou and Jinan. It was found that 2007 was the worst year and the haze frequencies from highest to lowest were Taiyuan, Shijiazhuang, Zhengzhou, Xingtai, Jinan, Beijing, and Tianjin.

\section{Air Pollution Control History and Emissions}

Hebei Province made a great effort on air pollution control since 1998 [21]. In 1998, air pollution control measurements focused on the key corporations, key industries and key regions, such as tourist regions and areas along the high way. In 1999, eleven cities were all required to make the comprehensive air pollution control action plan, and the mobile emission controls were strengthened as well.

In 2002, besides the continuous emission controls in major industries, the energy using in cities was paid more attention to and the central heating was pushed to spread in urban areas. In 2003, the provincial total amount control of $\mathrm{SO}_{2}$ was started, according to the national control plan. But it was found that the pollution emissions didn't decrease in the following three years, partially because of the unexpected rapid increase in energy consumption $[22,23]$.

In 2007, Hebei government released the Action Plan of the Comprehensive Controls of Flue Gas Emissions in Hebei Province. It required all the emission instruments reached the national emission standards before Jun. 2008. 
The explosive increase in vehicle population in Hebei Province was noticed and its pollution control was strengthened as well.

In 2008, the objectives of the Action Plan were accomplished and urban air quality was improved due to the flue gas cleaning, fugitive dust control and mobile source control. During the 2008 Beijing Olympics, lots of small industries, high-pollution plants were phase out or shutdown to ensure the good air quality in Beijing. It brought a better air quality in Hebei Province as well in this year. In 2009, the $\mathrm{SO}_{2}$ total amount control, energy optimizing in cities, moving high-pollution plants from our urban area were continuous pushing forward in $\mathrm{He}-$ bei Province.

In 2010, the national $\mathrm{SO}_{2}$ emission control objective was successfully accomplished [23]. Regional air quality jointly control and prevention were brought forward by MEP. Hebei government published the regional air pollution control guideline to accelerate the regional scale air quality improvement.

In the national 12th FYP of jointly air pollution prevention and control published in 2012, Beijing-TianjinHebei was listed in the three key regions. More effective controls could be expected under this action structure.

Figure 5 gives the provincial emissions of $\mathrm{SO}_{2}$, fly ash and dust emissions from 1998 to 2010. The data is come from the Report on the Environmental State of Hebei Province published every year by Hebei Environmental Protection Bureau (HBEPB) [21]. It can be seen that the total $\mathrm{SO}_{2}$ emissions decreased in 1998 to 2002 by $9.0 \%$ from the $1405 \mathrm{kt} \cdot \mathrm{y}^{-1}$ to $1279 \mathrm{kt} \cdot \mathrm{y}^{-1}$. Then it began to increase to $1545.5 \mathrm{kt} \cdot \mathrm{y}^{-1}$ in 2006 , which could partially attribute to the rapid increase of energy use during these five years [22,24]. After that it kept decreasing again, due to the effective national-scale $\mathrm{SO}_{2}$ emission controls during the 11th FYP (2006-2010) [23]. In 2010 the total $\mathrm{SO}_{2}$ emission was $1233.8 \mathrm{kt} \cdot \mathrm{y}^{-1}$, which is $20.2 \%$ lower than that in 2006. Figure 5 also indicated that industry

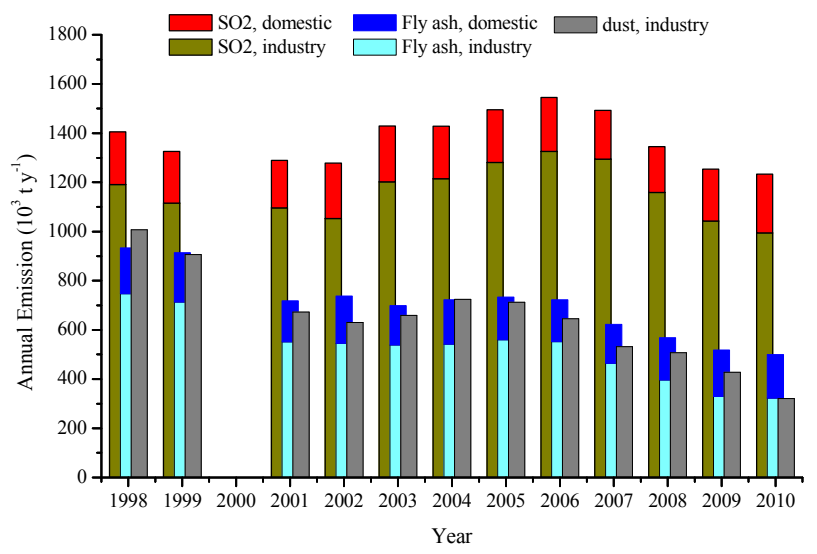

Figure 5. $\mathrm{SO}_{2}$, fly ash, and dust emissions in Hebei Province in 1998-2010. contributed most of the $\mathrm{SO}_{2}$ emissions in Hebei, which the fractions were between $80.6 \%$ (2010) to $86.7 \%$ (2007). The domestic emissions were relatively stable that kept between $186.4 \mathrm{kt} \cdot \mathrm{y}^{-1}$ (2008) to $239.6 \mathrm{kt} \cdot \mathrm{y}^{-1}$ (2010).

As to fly ash emissions, the general trend was decreasing, from $934 \mathrm{kt} \cdot \mathrm{y}^{-1}$ in 1998 to $499.7 \mathrm{kt} \cdot \mathrm{y}^{-1}$ in 2010. During 2001 to 2006 it kept relatively stable between 699 $\mathrm{kt} \cdot \mathrm{y}^{-1}$ to $738 \mathrm{kt} \cdot \mathrm{y}^{-1}$. After that the decreasing trend was obvious from $723.2 \mathrm{kt} \cdot \mathrm{y}^{-1}$ in 2006 by $30.9 \%$ to 499.7 $\mathrm{kt} \cdot \mathrm{y}^{-1}$ in 2010 . The industrial emission also accounted for a big fraction of $63.6 \%$ (2009) to $80.0 \%$ (1998).

The industrial dust emissions showed the similar variation as the $\mathrm{SO}_{2}$ emissions. The general trend was decreasing, from $1007 \mathrm{kt}^{-1}{ }^{-1}$ in 1998 by $68.1 \%$ to 320.9 $\mathrm{kt} \cdot \mathrm{y}^{-1}$ in 2010. The rapid decrease happened during the 11th FYP (2006-2010) as well.

\section{Conclusions}

Air pollution in Hebei Province has aroused a wide public concern, partially because of the severe fog-haze period happening in the beginning of 2013. It was reported that during this period, seven out of the top ten polluted cities in China were within Hebei Province. But, most of the previous studies involving Hebei focused on Beijing's air quality, the impact of Hebei's emissions to the air quality in Beijing, etc. Very few studies were pursued focusing on the severe air pollution within Hebei.

In this study, we reviewed and analyzed the air pollution history and status in Hebei Province, according to the API data and relative academic observations. It is concluded that air pollution in southern cities are much more severe than in northern cities. PM is the most important pollutant in Hebei cities, and $\mathrm{SO}_{2}$ and $\mathrm{NO}_{\mathrm{X}}$ pollution are unnegligible as well. $\mathrm{O}_{3}$ pollution in larger cities is significant, indicating that Hebei's cities are on the way from the coal-burning pollution to the mixed-source pollution. Visibility and haze frequencies in Hebei cities are discussed, that Hebei has both the highest number of haze days and the most rapid growth in haze frequency in recent years.

Hebei made a great effort on the air pollution control since 1998. The major air pollutant, such as $\mathrm{SO}_{2}$ and fly ash, showed a trend of increase in 2001 to 2006 and decrease since 2006. In 2012 MEP published national plan of the regional jointly air pollution prevention and control, more effective control strategies and measurement could be expected to improve the air quality in Hebei Province.

\section{Acknowledgements}

This study was sponsored by the National Natural Science Foundation of China (No. 41105105) and the Natu- 
ral Science Foundation of Hebei Province (No. D2011 402019).

\section{REFERENCES}

[1] MEP, "China National Ambient Air Quality Standards," GB3095-2012, MEP, Beijing, 2012.

[2] NBS (Natural Bureau of Statistics), "China Statistical Yearbook 2012," China Statistical Press, Beijing, 2012.

[3] NBS (Natural Bureau of Statistics), "China Energy Statistical Yearbook 2012," China Statistical Press, Beijing, 2012.

[4] Q. Zhang, D. G. Streets, G. R. Carmichael, K. B. He, H. Huo, A. Kannari, Z. Klimont, I. S. Park, S. Reddy, J. S. Fu, D. Chen, L. Duan, Y. Lei, L. T. Wang and Z. L. Yao. "Asian Emissions in 2006 for the NASA INTEX-B Mission," Atmospheric Chemistry and Physics, Vol. 9, 2009, pp. 5131-5153. doi:10.5194/acp-9-5131-2009

[5] L. T. Wang, P. Zhang, S. B. Tan, X. J. Zhao, D. D. Cheng, W. Wei, J. Su and X. M. Pan, "Assessment of Urban Air Quality in China Using Air Pollution Indices (APIs)," Journal of the Air \& Waste Management Association, Vol. 63, No. 2, 2013, pp. 170-178. doi:10.1080/10962247.2012.739583

[6] State Environmental Protection Agency of China, "China National Ambient Air Quality Standard (in Chinese)," GB3095-1996, State Environmental Protection Agency of China, Beijing, 1996.

[7] State Environmental Protection Agency of China, "China National Ambient Air Quality Standard (in Chinese)," GB3095-2012, State Environmental Protection Agency of China, Beijing, 2012.

[8] State Environmental Protection Agency of China, "Technical Regulations on Ambient Air Quality Index (in Chinese)," HJ633-2012, State Environmental Protection Agency of China, Beijing, 2012.

[9] D. S. Ji, Y. S. Wang, L. L. Wang, L. F. Chen, B. Hu, G. Q. Tang, J. Y. Xin, T. Song, T. X. Wen, Y. Sun, Y. P. Pan and Z. R. Liu, "Analysis of Heavy Pollution Episodes in Selected Cities of Northern China," Atmospheric Environment, Vol. 50, 2012, pp. 338-348. doi:10.1016/j.atmosenv.2011.11.053

[10] T. X. Wen, Y. S. Wang, H. H. Xu, Z. Q. Ma and S. D. Ji. "Comparison of the Characteristics of Ambient Pollutant $\mathrm{s}$ in Urban and Background Region in Beijing during August and September (in Chinese)," Research of Environmental Sciences, Vol. 20, No. 5, 2007, pp. 7-11.

[11] Y. P. Pan, Y. S. Wang, B. Hu, Q. Liu, Y. H. Wang and W. D. Nan, "Observation on Atmospheric Pollution in Xianghe During Beijing 2008 Olympic Games (in Chinese)," Environmental Science, Vol. 31, No. 1, 2010, pp. $1-9$.

[12] X. Y. Wang, J. Y. Xin, Y. S. Wang, X. X. Feng and Y. P. Zhang, "Observation and Analysis of Air Pollution in Tangshan During Summer and Autumn Time," Environmental Science, Vol. 31, No. 4, 2010, pp. 877-885.

[13] Y. Wu, "The Network Observation and Research on the Atmospheric Pollutants in Beijing, Zhuozhou, Baoding and Shijiazhuang," Master's Thesis, Nanjing University of Information Science \&Technology, 2011.

[14] W. P. Du, Y. S. Wang, T. Song, J. Y. Xin, Y. S. Cheng and D. S. Ji, "Characteristics of Atmospheric Pollutants during the Period of Summer and Autumn in Shijiazhuang," Environmental Science, Vol. 31, No. 7, 2010, pp. 1-8.

[15] P. Zhang, S. B. Tan, L. T. Wang, X. J. Zhao, J. Su, F. F. Zhang, Z. Wei, W. Wei and D. D. Cheng. "Characteristics of Atmospheric Particulate Matter Pollution in Handan City," Acta Scientiae Circumstantiae, (in Press).

[16] S. Z. Liu, X. Q. Li, S. Tao, Z. F. Tian, J. F. Wang and Y. Gao, "PAHs in the Atmosphere from the Area of Hebei, Beijing, and Tianjin during the Non-Heating Season," Acta Scientiae Circumstantiae, Vol. 28, No. 10, 2008, pp. 2105-2110. (in Chinese)

[17] H. Z. Che, X. Y. Zhang, Y. Li, Z. J. Zhou, J. J. Qu and X. J. Hao, "Haze Trends over the Capital Cities of 31 Provinces in China, 1981-2005," Theoretical and Applied Climatology, Vol. 97, No. 3-4, 2009, pp. 235-242. doi:10.1007/s00704-008-0059-8

[18] L. T. Wang, J. Xu, J. Yang, X. J. Zhao, W. Wei, D. D. Cheng, X. M. Pan and J. Su, "Understanding Haze Pollution over the Southern Hebei Area of China Using the CMAQ Model," Atmospheric Environment, Vol. 56, 2012, pp. 69-79. doi:10.1016/j.atmosenv.2012.04.013

[19] P. S. Zhao, X. L Zhang, X. F. Xu and X. J. Zhao, "Long-Term Visibility Trends and Characteristics in the Region of Beijing, Tianjin, and Hebei, China," Atmospheric Research, Vol. 101, No. 3, 2011, pp. 711-718, doi:10.1016/j.atmosres.2011.04.019

[20] D. Wu, X. J. Wu, F. Li, H. B. Tan, J. Chen, Z. Q. Cao, X. Sun, H. H. Chen, H. Y. Chen, "Temporal and spatial variation of haze during 1951-2005 in Chinese mainland (in Chinese)," Meteorologica Sinica, Vol. 68, 2010, pp. 680-688.

[21] HBEPB, "Report on the Environmental State in Hebei Province, 1998-2010," 2013. http://www.hb12369.net:8000/hjzlzkgb/

[22] L. T. Wang, C. Jang, Y. Zhang, K. Wang, Q. Zhang, D. Streets, J. Fu, Y. Lei, J. Schreifels, K. B. He, J. M. Hao, Y. F. Lam, J. Lin, N. Meskhidze, S. Voorhees, D. Evarts and S. Phillips, "Assessment of air Quality Benefits from National Air Pollution Control Policies in China. Part I: Background, Emission Scenarios and Evaluation of Meteorological Predictions," Atmospheric Environment, Vol. 44, No. 28, 2010, pp. 3442-3448. doi:10.1016/j.atmosenv.2010.05.051

[23] W. B. Xue, J. N. Wang, H. Niu, J. T. Yang, B. P. Han, Y. Lei, H. L. Chen and C. L. Jiang, "Assessment of Air Quality Improvement Effect under the National Total Emission Control Program during the Twelfth National Five-Year Plan in China," Atmospheric Environment, Vol. 68, No., 2013, pp. 74-81. doi:10.1016/j.atmosenv.2012.11.053

[24] L. T. Wang, C. Jang, Y. Zhang, K. Wang, Q. Zhang, D. Streets, J. Fu, Y. Lei, J. Schreifels, K. B. He, J. M. Hao, Y. F. Lam, J. Lin, N. Meskhidze, S. Voorhees, D. Evarts and S. Phillips, “Assessment of Air Quality Benefits from 
National Air Pollution Control Policies in China. Part II: Evaluation of Air Quality Predictions and Air Quality Benefits Assessment," Atmospheric Environment, Vol. 44,
No. 28, 2010, pp. 3449-3457.

doi:10.1016/j.atmosenv.2010.05.058 